Lepr Rev (1995) 66, 201-209.

\title{
Role of reactive oxygen species in renal damage in experimental leprosy
}

\author{
N. AGNIHOTRI*, N. K. GANGULY†, S. KAUR*, \\ M. KHULLAR $\dagger$, S. C. SHARMA* \& K. S. CHUGH $\ddagger$ \\ *Department of Dermatology, $\dagger$ Experimental Medicine and \\ $\ddagger$ Nephrology, Postgraduate Institute of Medical Education and \\ Research, Chandigarh-160012, India
}

Accepted for publication 25 April 1995

\begin{abstract}
Summary Renal involvement is known to occur in leprosy. In the present study the possible role of reactive oxygen species (ROS) in causation of renal damage in mice infected with Mycobacterium leprae has been investigated. At least six animals from each group (control and infected) were killed at 0 day, 3, 6 and 9 months postinfection. The results showed a significant increase in the chemiluminescence $(\mathrm{CL})$ response of peritoneal macrophages which was maximum between 3 and 6 months. No significant increase was observed in CL response of blood neutrophils. A significant increase in lipid peroxidation was observed at 3 and 6 months as evident by an increase in malondialdehyde levels. The increased ROS production might be the cause of lipid peroxidation. The renal damage is also evident by decrease in the activity of renal brush border membrane enzymes, namely, alkaline phosphatase, leucine aminopeptidase and r-glutamyl transpeptidase. Thus ROS might play a role during early stages of $M$. leprae infection but in the later stages other immunological mechanisms may overpower the effect of ROS.
\end{abstract}

\section{Introduction}

Renal involvement is known to occur throughout the spectrum of leprosy. The renal manifestations of leprosy need special attention as autopsy studies from India, Japan and Panama revealed that $11-37 \%$ of leprosy patients die of renal failure. ${ }^{1}$ Recently Rajan et al. ${ }^{2}$ reported that mortality due to renal failure was the single largest cause of death among leprosy patients. It is important therefore, to be aware of renal manifestations of leprosy.

The exact mechanisms of renal involvement in leprosy is not known. Most of the studies done to date have focused attention on the histopathological, immunological, bacteriological and functional aspects. However, very little information is available regarding the biochemical mechanisms involved in renal damage. Renal dysf unction may be present even in the absence of morphological changes. The aetiology of this 
dysf unction whether, Mycobacterium leprae or some other simultaneous infection is not known. ${ }^{3}$ The aetiology and pathogenesis of renal disease in leprosy, therefore, appears to be complex and multifactorial.

Since $M$. leprae is an intracellular pathogen and immune complexes are known to occur in leprosy, the possible role of reactive oxygen species needs evaluation. The reactive oxygen species (ROS), which include superoxide anion $\left(\mathrm{O}_{2}{ }^{-\bullet}\right)$ hydrogen peroxide $\left(\mathrm{H}_{2} \mathrm{O}_{2}\right)$, hydroxyl radical $\left(\mathrm{OH}^{\bullet}\right)$ and singlet oxygen $\left({ }^{1} \mathrm{O} 2\right)$ are produced by univalent reduction of molecular oxygen. Such ROS are being increasingly recognized as mediators of cell injury in various pathogenic states. ${ }^{4,5}$ Although all the cell components are susceptible to attack by free radicals, lipids; particularly those containing unsaturated fatty acids, are notably so. ${ }^{6,7}$ The oxidation of lipids by these radicals generates a series of lipid peroxides, hydroperoxides and aldehydes which are highly reactive and toxic. ${ }^{8}$ The ROS mediated tissue damage can be demonstrated by measuring malondialdehyde (MDA), a product of lipid peroxidation. The formation of lipid hydroperoxides in membranes would result in damage of the membrane structure ${ }^{9,10}$ and the inactivation of membrane-bound enzymes. ${ }^{11,12}$ In the present study, we have investigated the possible role of ROS in causation of renal damage. The production of ROS was evaluated by measuring the chemiluminescence response of peritoneal macrophages and blood neutrophils and renal damage was studied by measuring malondialdehyde level and assessing specific renal brush border enzymes, namely, alkaline phosphatase, leucine aminopeptidase and r-glutamyl transpeptidase.

\section{Materials and methods}

\section{EXPERIMENTAL MODELS AND GROUPS}

Closely bred lacca strain of Swiss albino mice (susceptible to footpad infection by $M$. leprae), 3-4 weeks old and raised in the Central Animal House of the Postgraduate Institute of Medical Education \& Research, Chandigarh, India were used in the present study. The animals were divided into two groups:

Group I consisted of 60 normal mice injected with normal saline in the right-hand footpad and served as control group.

Group II included 60 mice given $M$. leprae infection $\left(1 \times 10^{4} M\right.$. leprae s/c) in the righthind footpad by the method of Shepard ${ }^{13}$ using human skin biopsies from lepromatous leprosy (LL) patients with high bacillary counts (BI $4+$ to $6+$ ).

The animals from each group were killed periodically at 0 day, 3,6 and 9 months after removing peritoneal fluid and blood. All the experiments were carried out in triplicate and the following investigations were carried out.

\section{SEPARATION OF PERITONEAL MACROPHAGES AND BLOOD NEUTROPHILS}

The peritoneal macrophages were obtained by the method as described by McCarron et $a l{ }^{14}$ without injecting any eliciting agent. Briefly, the peritoneal macrophages were obtained by injecting McCoy's medium into the side of abdominal cavity and the distended peritoneal cavity was massaged gently and the fluid was aspirated out. The cells were then washed twice in McCoy's medium by centrifugation $(225 \times \mathrm{G}, 10 \mathrm{~min}$ at $4^{\circ} \mathrm{C}$ ) and suspended in $2 \mathrm{ml}$ of McCoy's medium. The cells were kept for sticking in 
$35 \mathrm{~mm}$ petriplates at $37^{\circ} \mathrm{C}$ in a humidified $\mathrm{CO}_{2}$ and $95 \%$ air atmosphere for $90 \mathrm{~min}$ and the adherent cells were detached gently with a rubber policeman. The cells were aspirated out, counted and diluted.

For isolation of neutrophils, blood was collected by cardiac puncture and transferred to a siliconized centrifuge tube containing $0.2 \mathrm{ml}$ of $3.5 \%$ dextran and $20 \mu \mathrm{l}$ heparin. The tubes were shaken and kept at room temperature for settling of the dextral red cell agglutinates. Neutrophils were separated from the blood by the method of Boyum. ${ }^{15}$ Briefly, the leukocyte-rich plasma was layered on the Ficoll isopaque gradient and centrifuged for $30 \mathrm{~min}$ at $4^{\circ} \mathrm{C}$. In the pallet thus obtained, red blood cells were lysed by subjecting to osmotic shock lysis by using $0 \cdot 87 \%$ chilled $\mathrm{NH}_{4} \mathrm{Cl}$ for $15 \mathrm{~s}$. Subsequently McCoy's double strength medium was added and centrifugation at $200 \times \mathrm{G}$ for 5 min was done at $4^{\circ} \mathrm{C}$. The pallet containing neutrophils was finally suspended in Minimum Essential Medium (MEM) without indicator at $\mathrm{pH} 7 \cdot 2$.

The viability of the cells (peritoneal macrophages and blood neutrophils) was checked using the Trypan blue exclusion method Tennant ${ }^{16}$ and the final concentration of the cells was adjusted to $2 \times 10^{6} / \mathrm{ml}$.

\section{CHEMILUMINESCENCE ASSAY}

The chemiluminescence $(C L)$ response of blood neutrophils and peritoneal macrophages was measured by the method of Cheung et al. ${ }^{17} 10 \mu \mathrm{l}$ of luminol $(5 \mathrm{mg} / \mathrm{ml}$ of $0 \cdot 1 \mathrm{~N}$ $\mathrm{NaOH}$ ) was used as a chemilugenic probe for the amplification of luminescence and latex $(20 \mu \mathrm{l})$

Berthhold luminometer (Biolumat LB 9500C) adjusted at an integration mode and at $37^{\circ} \mathrm{C}$. The results were expressed as counts per minute per million cells (cpm/10 6 cells).

PREPARATION OF RENAL BRUSH BORDER MEMBRANE VESICLES (BBMV)

The renal BBMV were prepared by the method of Malathi et al. ${ }^{18}$ as modified by Turner \& Moran. ${ }^{19}$ Briefly, after decapsulation renal cortex was removed and suspended in homogenizing buffer. The tissue was homogenized for $10 \mathrm{~min}$ at full speed in a tissue homogenizer. The resulting homogenate was left on ice for $10 \mathrm{~min}$ with $\mathrm{CaCl}_{2}$. After differential centrifugations the pallet obtained was suspended in the reconstitution buffer containing $300 \mathrm{mM}$ mannitol, $1 \mathrm{mM}$ Tris buffer at $\mathrm{pH} 7.5$ and repeatedly passed through a 25 gauge needle. The vesicle preparation was finally incubated at $30^{\circ} \mathrm{C}$ for $15-20 \mathrm{~min}$ and then stored at $20^{\circ} \mathrm{C}$ until used.

\section{ESTIMATION OF MALONDIALDEHYDE (MDA)}

MDA was estimated by the method of Maridonneau et al. ${ }^{20}$ The rate of formation of MDA, a thiobarbituric acid reactive substance, was assayed in renal BBMV spectrophotometrically at $535 \mathrm{~nm}$ after its extraction into butanol layer. 1,1,3,3-tetra ethoxypropane was used as standard. The amount of MDA formed was expressed as $n$ mole $/ \mathrm{mg}$ protein.

Proteins in the renal BBMV were estimated by. the method of Lowry et al. ${ }^{21}$ 
ASSAY OF RENAL BBM ENZYMES

The biochemical assessment of the activity of enzymes known to be characteristic of a renal brush border membrane, namely alkaline phosphatase (AP), leucine aminopeptidase (LAP) and $\gamma$-glutamyl transpeptidase $(\gamma-\mathrm{GT})$ was done by the methods of Bergmeyer et al., ${ }^{22}$ Goldberg \& Rutenberg ${ }^{23}$ and Naftalin et al. ${ }^{24}$ respectively.

\section{ASSESSMENT OF BACILLARY GROWTH}

The footpads of mice were used to harvest acid-fast bacilli (AFB) as described by Desikan \& Venkataramariah. ${ }^{25}$

\section{STATISTICAL ANALYSIS}

The statistical significance was calculated using students' $t$-test. All the values have been presented as mean \pm standard deviation (SD) of triplicates.

\section{Results}

CHEMILUMINESCENCE RESPONSE OF PERITONEAL MACROPHAGES

A marked increase $(P<0.001)$ was observed in the $\mathrm{CL}$ response of peritoneal macrophages at 3,6 and 9 months in the infected group as compared to the control group. However, the CL response at 9 months was much less compared to that observed at 3 months (Figure 1).

A slight increase $(P<0.05)$ in CL response of blood neutrophils was observed in the infected group $(751 \cdot 28 \pm 33 \cdot 04)$ as compared to the control group $(698 \cdot 87 \pm 42 \cdot 43)$ only at 6 months (Figure 2).

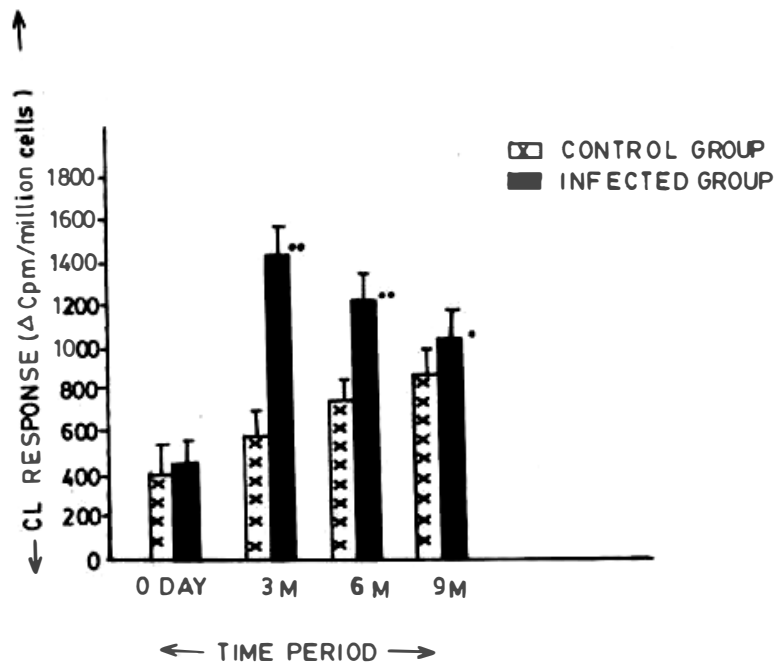

Figure 1. Chemiluminescence response of peritoneal macrophages (cpm/10 cells) of control and infected groups at 0 day, 3, 6 and 9 months postinf ection. 


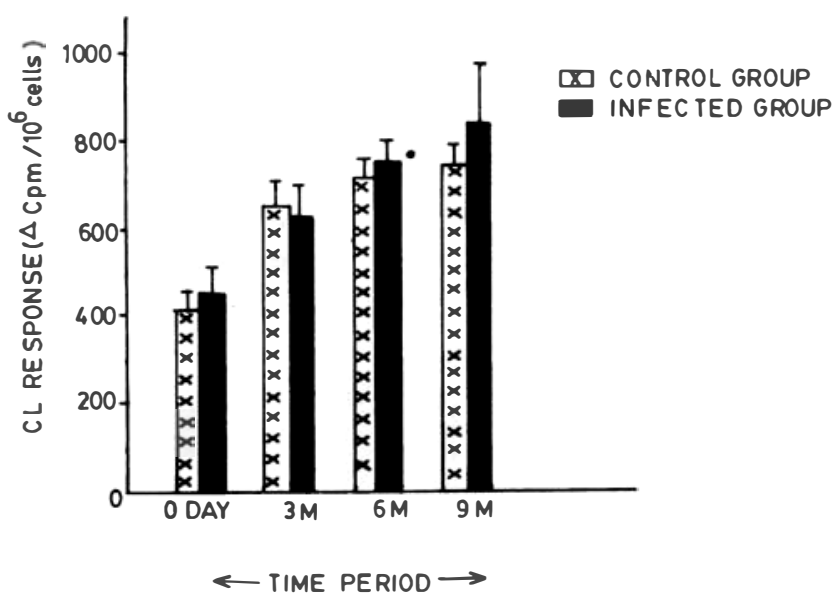

Figure 2. Chemiluminescence response of blood neutrophils ( $\mathrm{cpm} / 10^{6}$ cells) of control and inf ected groups at 0 day, 3, 6 and 9 months postinfection.

\section{MALONDIALDEHYDE PRODUCTION}

A significant increase $(P<0 \cdot 001)$ was found in MDA at 3 and 6 months as a result of $M$. leprae infection in the infected group as compared to the control group (Figure 3).

\section{ACTIVITY OF BBM ENZYMES}

\section{Activity of alkaline phosphatase}

The enzyme activity in the infected group was found to be decreased significantly at 3 $(P<0.01), 6(P<0.001)$ and nine months $(P<0.001)$ when compared to the control groups (Figure 4).

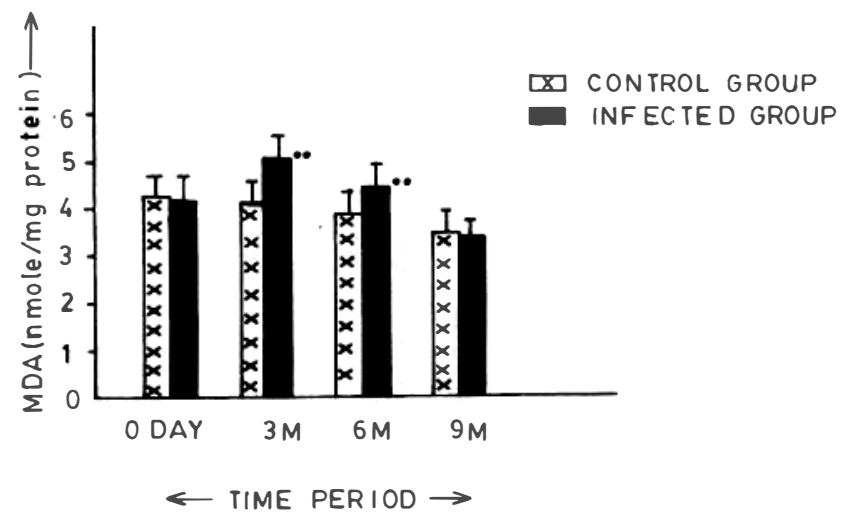

Figure 3. Malondialdehyde content ( $n$ moles/mg protein) in brush border membrane vesicles from kidneys of control and infected groups at 0 day, 3, 6 and 9 months postinfection. 


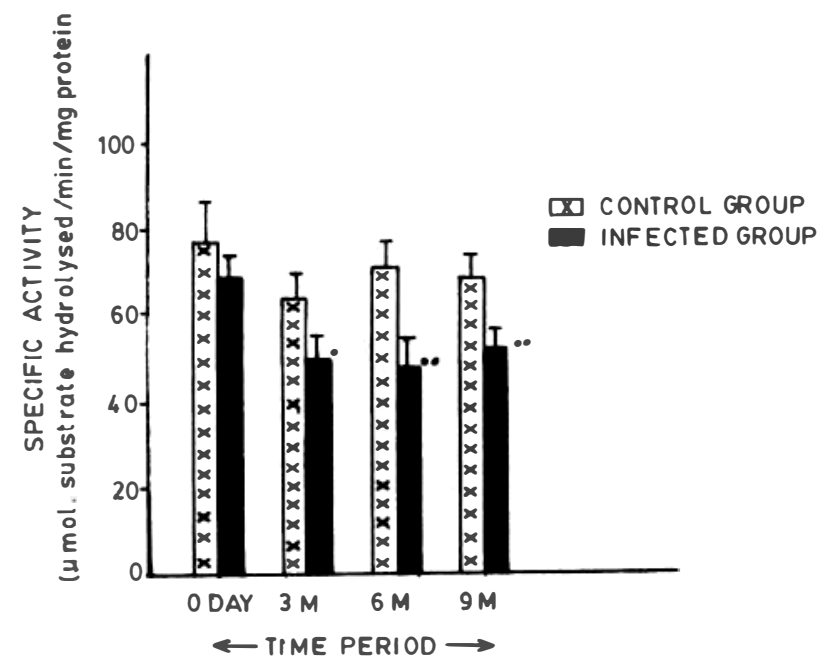

Figure 4. Specific activity of alkaline phosphatase in renal brush border membrane vesicles at 0 day, 3, 6 and 9 months postinfection.

\section{Activity of Leucine aminopeptidase}

A significant decline in the activity of this enzyme was observed in infected groups at 3 $(P<0.01), 6(P<0.001)$ and 9 months $(P<0.01)$ as compared to their control groups (Figure 5).

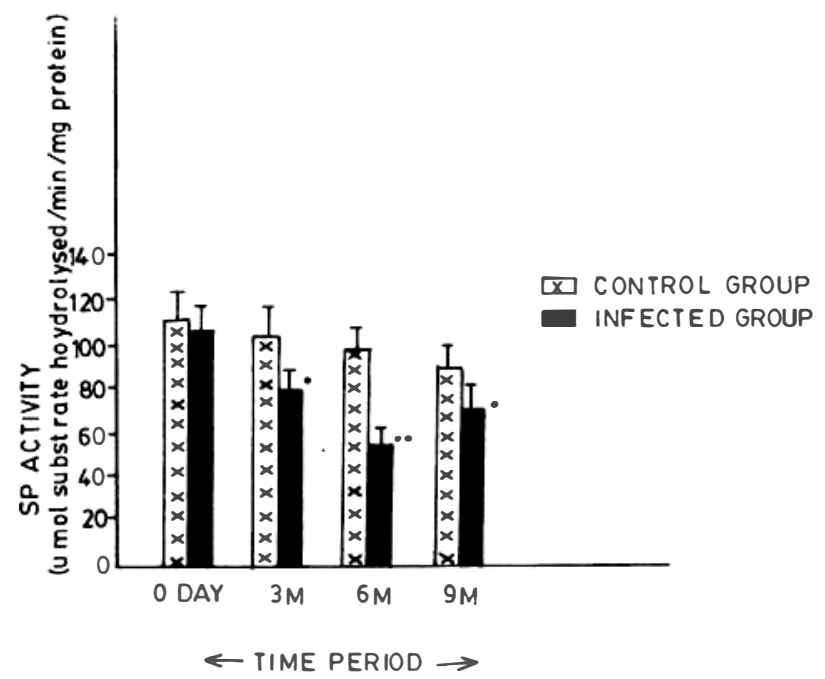

Figure 5. Specific activity of leucine amino peptidase in renal brush border membrane vesicles at 0 day, 3, 6 and 9 months postinfection. 


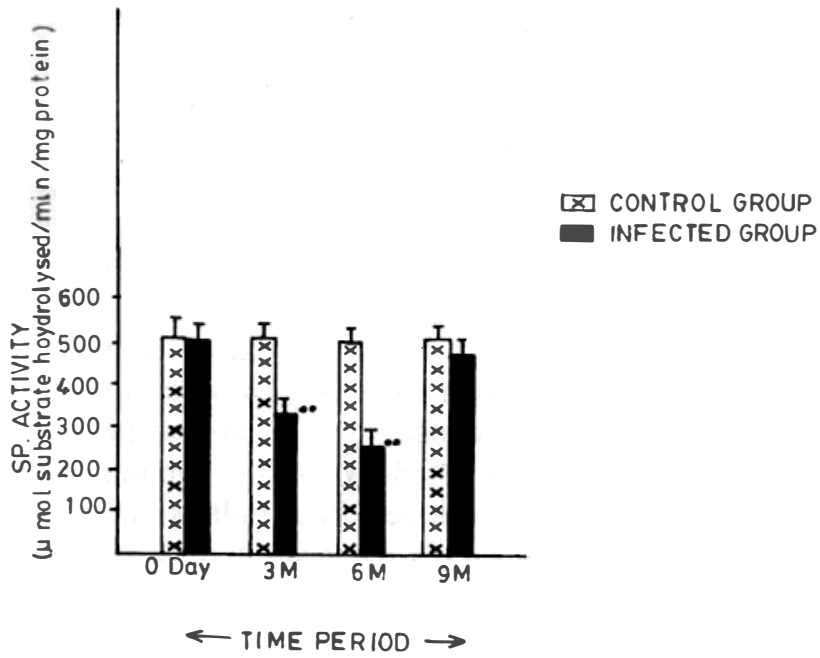

Figure 6. Specific activity of $\gamma$-glutamyl transpeptidase in renal brush border membrane vesicles at 0 day, 3,6 and 9 months postinfection.

\section{Activity of $\gamma$-glutamyl transpeptidase}

A marked decrease $(P<0.001)$ in the enzyme activity was observed in the infected group at 3 and 6 months as compared to the control groups. However, at 9 months, no significant difference was observed in the activity of this enzyme between infected and control groups (Figure 6).

\section{BACTERIAL FOOTPAD COUNTS}

The bacterial footpad counts were found to follow the characteristic patterns of growth after inoculation with $M$. leprae. The bacterial footpad counts increased linearly from 3 to 6 months from $0.892 \times 10^{4} \pm 0.36 \times 10^{4}$ to $2.45 \times 10^{5} \pm 0.92 \times 10^{5}$ reaching a stationary phase of growth at the end of 9 months when the counts were $2 \cdot 28 \times 10^{5} \pm 0.23 \times 10^{5}$.

\section{Discussion}

The results of the present study show that there is an increase in chemiluminescence response at 3,6 and 9 months postinfection with $M$. leprae. The response was maximum at 3 months. The ROS production showed a good correlation with peak bacterial counts in the mouse footpads. The bacterial footpads pattern showed a linear increase from 3 to 6 months postinfection, representing the logarithmic phase of organism. However, at 9 months postinfection, stationary phase of bacillary growth is reached. The higher ROS production as indicated by CL response could be due to bacterial load which lead to greater stimulation. Brett \& Butler ${ }^{26}$ observed higher monocyte/macrophage activation in the BALB/c strain of mice which is susceptible to M. lepraemurium infection than C57 BL strain of mice which are resistant to infection. Our results indicate that there is an 
increased production of ROS initially on stimulation as indicated by CL response but later some other suppressor mechanisms start acting, making the production of ROS inactive. This could be due to an increase in the bacterial load.

Our results indicate no significant increase in the CL response of blood neutrophils at 3 and 9 months and a slight increase was observed at 6 months only. This could be due to the fact that although neutrophils are phagocytic and constitute the first line of defence, they are conspicuous by their absence in the typical lesions of leprosy.

In cell-mediated immunity, prominent role is played by macrophages. Macrophage functions and their immune mechanisms play a very important role in the spectrum of leprosy throughout. Macrophages also constitute a prominent part of renal lesions as is evident by histopathological alterations in kidneys of these animals at 3,6 and 9 months postinfection with $M$. leprae (data not included). The inflammatory cells in renal lesions consisted chiefly of mononuclear cells, plasma cells and lymphocytes. To study the chemiluminescence response of phagocytes, in the present study blood neutrophils and peritoneal macrophages were used. This indirect approach was adopted because of the difficulties in harvesting an adequate number of blood monocytes and renal macrophages.

The observed increase in MDA levels in the infected group at 3 and 6 months reflects increased lipid peroxidation. These two parameters (CL response and MDA production) are well correlated, thereby demonstrating that tissue damage is due to ROS at 3 and 6 months.

ROS can cause lipid peroxidation and disrupt membrane functions. The decrease in the activities of enzymes indicating renal damage, was found to correspond to the increased levels of MDA. A positive correlation between the two demonstrated that the tissue damage might be a direct consequence of lipid peroxidation. Lipid peroxidation have been shown to produce various toxic effects on cell structure as well as function including changes in membrane fluidity, permeability and loss of membrane integrity, protein degradation and ultimately cell $\operatorname{lysis}^{27}$. As a result of lipid hydroperoxide formation in membranes, damage to the membrane structure ${ }^{9,10}$ and inactivation of membrane-bound enzymes ${ }^{11,12,28}$ could result. The activities of various BBM enzymes have been reported to be decreased in the renal BBM during pyelonephritis and could be used as biochemical markers of tissue in jury or the disease. ${ }^{29}$ The activities of renal BBM enzymes have also been found to decrease in experimental leprosy. This has been further confirmed by altered transport of nutrients across renal brush border membrane in experimental leprosy. ${ }^{30}$

Although the effects seen in the mouse model are very transient, these might form a nidus for further damage in this infection. The ROS production might play a role in renal damage at early stages of $M$. leprae infection. In the later stages, other immunological mechanism may overpower the effect of ROS.

In human lepromatous leprosy, the secretion of renal brush border enzymes, namely alkaline phosphatase, leucine aminopeptidase and r-glutamyl transpeptidase has been reported. ${ }^{31}$ It appears that the damage to renal tubules is caused by M. leprae or immune complexes leading to the shedding of these enzymes in the urine. The findings of increased secretion might be helpful in the early detection of renal involvement in leprosy patients and may possibly serve as an indicator of the response to multidrug therapy or a relapse in treated patients, as the present paper shows that these might be operative at a renal level. 


\section{References}

${ }^{1}$ Chugh KS and Sakhuja V. Renal lesions in leprosy. JAPI, 1991; 39(2): 163-164.

2 Rajan MA, Balakrishnan S, Manoharan A, Balamurugan M, Narayanakumar TS. Incidence and clinical profile of renal failure of leprosy patients. A retrospective study for five years 1986-1990. (Abstract) Ind J Lepr, 1992; 64(22): 243.

${ }^{3}$ Kaur S. Renal manif estations of leprosy. Ind J Lepr, 1990; 62(3): 273-280.

4 Sangey H. The pathogenesis of acute pancreatitis the source and role of oxygen derived free radicals in three different experimental models. Ann of Surg, 1984; 201(2): 633-638.

5 Johnson RH, Klebanoff SH and Couser WG. The myeloperoxidase hydrogen peroxide halide system. A new mediator of glomerulonephritis. Kidney Int, 1986; 29: 278.

6 Freeman BA and Crapo JD. Free radicals and tissue injury. Lab Invest, 1982; 47: 412-426.

7 Clark IA and Cowden WB. Antimalarials. In. Sies H, ed. Oxidative stress, London. Academic Press, 1985; $131-149$.

8 Esterbaurer H. Aldehydic products of lipid peroxidation. In. McBrien DCH, Slater TF, (Eds). Free radicals, lipid peroxidation and cancer. London, Academic Press, 1982; 101-128.

9 Lai CS and Piette LH. Spin-trapping studies of hydroxyl radial production involved in lipid peroxidation. Arch Biochem Biophys, 1978; 190: 27-38.

10 Tien M, Svingen BA and Aust SD. An investigation into the role of hydroxyl radical in xanthine oxidase dependent lipid peroxidation. Arch Biochem Biophys, 1982; 216: 142-151.

11 Wills ED. Effects of lipid peroxidation on membrane bound enzymes of the endoplasmic reticulum. Biochem $J, 1971$; 123: 983-991.

12 Plaa GL and Witschi H. Chemicals, Drugs and lipid peroxidation. Ann Rev Pharmacol Toxicol, 1976; 16: $125-141$.

13 Shepard CC. The experimental disease that follows the in jection of human leprosy bacilli into footpads of mice. $J$ Exp Med, 1986; 112: 445-454.

14 McCarron RM, Goroff DK, Luhr JE, Murphy MA, Herscowitz HE. Methods for the collection of Peritoneal and Alveolar macrophages. Methods in Enzymology, 1984; 108: 274-284.

15 Boyum A. Isolation of mononuclear cells and granulocytes from human blood. Scand J Clin Lab Invest, 1968; 21(Suppl 9): 77-89.

16 Tennant JR. Evaluation of trypan blue technique for determination of cell viability. Transplantation, 1964; 2: 685 .

17 Cheung K, Archibald AC and Robinson MF. Chemiluminescence produced by PMNs stimulated by immune complex. Aust J Exp Biol Med Sci, 1984; 62: 403-419.

18 Malathi P, Preiser H, Faire-Laugh P, Mallet P and Crane RK. A rapid method for the isolation of kidney brush border membranes. Biochem Biophys Acta, 1979; 554: 259-263.

19 Turner R J and Moran A. Heterogeneity of sodium dependent D-glucose transport sites along the proximal tubule: evidence from vesicle studies. Am J Physiol, 1982; 42: F406-F414.

20 Maridonneau I, Braquet $\mathrm{P}$ and Gray RP. $\mathrm{Na}^{+}$and $\mathrm{K}^{+}$transport damage induced by oxygen free radicals in human red cell membranes. $J$ Biol Chem 1983; 258 (5): 3107-3113.

21 Lowry OH, Rosebrough NK, Farr AL and Randall RJ. Protein measurement with Folin phenol reagent. J Biol Chem, 1951; 193: 265-275.

22 Bergmeyer MVC. Methods of enzymatic analysis. Academic Press, New York. 1963; 783.

23 Goldberg JA and Rutenberg AM. The calorimetric determination of leucine aminopeptidase in urine and serum of normal subjects and patients with cancer and other diseases. Cancer, 1958; 11: 283-291.

24 Naftalin L, Sexton M and Whitaker JF. A routine procedure for estimating serum r-glutamyl transpeptidase activity. Clin Chim Acta, 1969; 26: 293-296.

25 Desikan KV and Venkataramariah HN. A modified method of harvesting M. leprae from foot pads of mice. Lepr India, 1976; 48: 157.

26 Brett SJ and Butler R. Macrophages activity in resistant and susceptible mouse strains infected with Mycobacterium lepraemurium. Immunology, 1988; 63: 701-706.

27 Halliwell B and Gutteridge JMC. Oxygem radicals and tissue damage. Adv Studies Heart Metab, 1982; 403411.

28 Sun AY. The effect of lipoxidation on synaptosomal $\left(\mathrm{Na}^{+} \mathrm{K}^{+}\right)$-ATPase isolated from the cerebral cortex of squirrel monkey. Biochem Biophys Acta, 1972; 266: 350-360.

29 Garg UC, Ganguly NK, Sharma S and Bhatnagar R. Antipili antibody affords protection against ascending pyelonephritis in rat; evaluated by renal brush border membrane enzymes. Biochem Int, 1987; 14: 517-524.

30 Kohli M, Sharma VK, Vaishnavi C, Ganguly NK, Kaur S and Chugh KS. Renal brush border membrane vesicle study of marker enzymes and uptake of nutrients in Mycobacterium leprae infected mice. Japan J Exp Med, 1990; 60(5): 285-290.

31 Kohli M, Vaishnavi C, Garg UC, Ganguly NK and Kaur S. Urinary excretion of renal brush border enzymes in lepromatous leprosy. Int J Lepr, 1989; 57: 220-223. 